\title{
APROVAÇÃO EM CONCURSO PÚBLICO E DIREITO SUBJETIVO À NOMEAÇÃO
}

\author{
Francisco MaURo Dias \\ THEOPHILO ANTONIO MigUEL FILHO
}

I - Problemática. II - Objetivos. III - Justificativa. IV - Metodologia e técnicas utilizadas. V-Desenvolvimento. VI - Conclusão. VII Bibliografia.

\section{I-Problemática}

Não são raras as vezes em que o candidato aprovado em concurso público comparece ao Poder Judiciário para pedir que a esfera do Poder Público responsável pela realização do certame seja compelida a nomeá-lo para o cargo almejado.

Tal pretensão exurge quando, a despeito da aprovação e classificação dentro do número de vagas expressamente previsto no edital, a Administração Pública queda-se inerte, ou, ainda, quando, durante o prazo de eficácia ${ }^{1}$ do certame, cargos tornam-se vagos em virtude de transferências, aposentadorias ou óbitos de seus ocupantes.

As razões expendidas abordam o inconformismo com a conduta omissiva e excessiva delonga na nomeação, já que não seria razoável, além de ferir o princípio da moralidade administrativa, que, a despeito da existência de cargos vagos, se realizasse um custoso e demorado concurso público para o provimento dos mesmos única e exclusivamente com a finalidade de arrecadar o valor cobrado a título de inscrição, o qual, invariavelmente, é elevado.

1 Afirma Sergio de Andréa Ferreira, in Comentários à Constituição, $3^{\circ}$ volume, 1991, Biblioteca Jurídica Freitas Bastos, página 150, que "a CF, no inciso III do artigo 37, fixou o que rotula de prazo (máximo) de validade do concurso público. Repete, assim, equívoco, generalizado, encontradiço na própria legislação, porquanto o prazo é ligado ao plano de eficácia, e não de validade. Em verdade, a limitação temporal diz respeito ao efeito produzido, ou seja, à habilitação que resulta da aprovação no concurso homologado, e, quando, é o caso, da correspondente ordem classificatória. É, pois, questão de vigência desse efeito, que tem prazo preclusivo." 
Por intermédio do presente trabalho, pretende-se demonstrar a insubmissão do Poder Público ao dever jurídico de nomear candidato aprovado em certame, em que pese a vacância de cargos.

\section{III - Justificativa}

A importância deste estudo se justifica para preservar a integridade de diversos princípios do Direito Administrativo, como o da razoabilidade, o da moralidade, bem como o da separação dos Poderes, a fim de coibir indevidas ingerências do exercício da função jurisdicional em misteres exclusivamente atinentes aos da função administrativa, evitando a proliferação de práticas processuais que enfraqueçam a segurança jurídica e acarretem instabilidade nas relações políticas.

\section{IV - Metodologia e técnicas utilizadas}

A pesquisa jurisprudencial e doutrinária será o método utilizado para se alcançar a conclusão.

\section{$V-$ Desenvolvimento}

A controvérsia acerca da existência de direito subjetivo à nomeação de candidato aprovado em concurso público suscita intermináveis debates acerca de questões jurídicas de alta indagação, envolvendo seara constitucional e administrativa.

Ensina-nos San Tiago Dantas ${ }^{2}$ que em toda relação jurídica, consubstanciada em uma relação social especialmente qualificada pela norma jurídica, encontra-se como seu elemento fundamental o dever jurídico. Esse dever se deduz da própria norma jurídica que qualifica aquela relação. Ou é o dever de fazer aquilo que a norma ordena, quando a norma contém o comando, ou é o dever de respeitar os efeitos jurídicos da norma, quando a norma se limita a atribuir efeitos jurídicos, ou, então, quando a norma foi violada, a esse dever corresponde um direito de uma outra pessoa de exigir o cumprimento do dever.

Destarte, conclui-se que a relação jurídica compõe-se de dois elementos indissociáveis: o dever jurídico e o direito subjetivo. Este último é identificável segundo a presença de três elementos:

a) este direito subjetivo é sempre decorrência de um dever jurídico;

b) o direito subjetivo é violável;

c) o titular do direito subjetivo pode ter a iniciativa da coerção para fazer a parte contrária sucumbir à sua pretensão surgida da violação do dever jurídico. 
Assim, direito subjetivo e dever jurídico são os dois lados da mesma moeda denominada relação jurídica.

Não há que se falar em direito subjetivo se não preexistir um dever jurídico a ser desrespeitado. A existência deste é conditio sine qua non para que se Cogite daquele.

Neste exato momento vem à baila a inexorável indagação: tem o candidato aprovado em concurso público direito subjetivo à nomeação?

Esta pergunta equivale a outra de igual quilate: tem a Administração Pública o dever jurídico de proceder à nomeação de candidato aprovado em concurso público?

A resposta da última conduzirá à solução daquela.

Doutrina e jurisprudência incumbiram-se de responder. Conforme Diógenes Gasparini ${ }^{3}$,

Concurso público é o procedimento posto à disposição da Administração Pública direta e indireta, de qualquer nível de governo, para a seleção do futuro melhor servidor, necessário à execução de serviços que estão sob sua responsabilidade. Não é, assim, procedimento de simples habilitação. É um processo competitivo, onde as vagas são disputadas pelos vários candidatos. Nenhum direito subjetivo tem à nomeação. Pelo concurso concretiza-se o Princípio da Igualdade.

Referindo-se ao prazo de validade do concurso público (artigo 37, inciso III, Constituição da República), comenta, ainda, o insigne administrativista que nada impede que, durante o prazo de validade de um concurso, outro seja aberto, levado a efeito e classificados os aprovados. O que não se pode dentro desse prazo é nomear os classificados de um concurso posterior, enquanto existirem concursados anteriores a serem nomeados.

Outro não foi o entendimento esposado pela Eminente Desembargadora Federal Tania Heine ${ }^{4}$, em voto proferido perante julgamento realizado no Egrégio Tribunal Regional Federal da $2^{\mathrm{a}}$ Região, cuja ementa segue in verbis:

I - Concurso público para professor assistente, constando do edital a existência de uma vaga, com aprovação de quatro candidatos.

II - os aprovados têm prioridade sobre novos concursados (art. 37 da CF) dentro do prazo de validade do concurso (art. 12 , $2^{\circ}$, da Lei $8.112 / 90$ ).

III - Aberta outra vaga, dentro do prazo de validade do concurso, o segundo colocado tem direito de ser convocado prioritariamente, antes dos aprovados no concurso seguinte.

3 Direito Administrativo, Saraiva, $3^{\text {a }}$ edição, página 129.

4 Apelação em Mandado de Segurança 93.02.20733-1/RJ, publicado no DJU-II de 09/08/94, página 42.213 . 
IV - Recurso e remessa necessária improvidos.

Ainda em seu voto, cita a Magistrada as elucidativas lições do saudoso Hely Lopes Meirelles:

"Ainda mesmo a aprovação no concurso não gera direito absoluto à nomeação. pois que continua o aprovado com simples expectativa de direito à investidura no cargo disputado.

Vencido o concurso, o primeiro colocado adquire direito subjetivo à nomeação com a preferência sobre qualquer outro, desde que a Administração se disponha a prover o cargo, mas a conveniência e oportunidade do provimento ficam à inteira discrição do Poder Público. O que não se admite é a nomeação de outro candidato, que não o vencedor do concurso".

Trazemos, ainda, à colação o entendimento do Eminente Ministro Hélio Mosi$m a n n^{6}$, em julgamento realizado no Superior Tribunal de Justiça, in verbis:

“...

Sabemos que o princípio norteador da matéria é o de que a aprovação em concurso público não obriga o candidato, ao qual aproveita mera expectativa de direito à almejada nomeação".

Nesse mesmo sentido:

"Recurso em mandado de segurança. Concurso público. Aprovação. Nomeação.

A aprovação em concurso público confere ao candidato expectativa à nomeação. Não tem direito de exigi-la. Ilegalidade haverá caso a pública administração promova nomeação em desrespeito à ordem de classificação." 7

Destarte, impende tecer algumas considerações de ordem prática para perfeito delineamento da vexata quaestio.

Aprovação e classificação em concurso público não se confundem.

A primeira é conferida aos que obtiverem logrado o grau mínimo. Entretanto, estes não se podem dizer classificados, eis que se encontram na dependência da existência de vagas, que é fator meramente circunstancial.

Tanto aos aprovados classificados quanto aos aprovados não classificados reconhece-se direito subjetivo tão-somente à estrita observância da ordem classifica-

5 Direito Administrativo Brasileiro, 1966, página 365.

6 Recurso em Mandado de Segurança 1585-3/MG, RSTJ 67/267.

7 ROMS n 494/MS, Ministro Vicente Cernicchiaro, e também RSTJ 66/213. 
tória para que se proceda à nomeação. porque a este direito corresponde o dever jurídico da Administração Pública em manter imaculado o Princípio Constitucional da Impessoalidade e Moralidade, insculpidos no caput do artigo 37 da Carta Magna.

Possuem mera expectativa de direito à nomeação, segundo a análise meritória da conveniência e oportunidade da prática do ato. Lesão apta a ensejar tutela jurisdicional só surgirá se e quando for inobservada a ordem de classificação.

Daí porque compelir a Administração Pública a nomear o candidato para o cargo almejado esbarra em quebra do Princípio da Separação dos Poderes, insculpido no artigo $2^{\circ}$ da Constituição da República, consubstanciando-se em ingerência exacerbada e indevida de um Poder (rectius Órgão) em misteres exclusivos atinentes a outro.

A Constituição do Estado do Rio de Janeiro, no artigo 77, inciso VII, assim dispõe:

“ A administração pública direta, indireta ou fundacional, de qualquer dos Poderes do estado e dos Municípios, obedecerá aos princípios da legalidade, impessoalidade, moralidade, publicidade, interesse coletivo e, também, ao seguinte:

VII - a classificação em concurso público, dentro do número de vagas obrigatoriamente fixado no respectivo edital, assegura o provimento no cargo no prazo máximo de cento e oitenta dias, contado da homologação do resultado."

Ocorre que o Supremo Tribunal Federal, em mais de uma ocasião, se posicionou, incidenter tantum, pela inconstitucionalidade do mandamento constitucional acima indigitado, corroborando, destarte, o entendimento que ora se expõe:

"Concurso público. Artigo 77, inciso VII, da Constituição do Estado do Rio de Janeiro, que cria direito à nomeação dos candidatos aprovados dentro do número de vagas e no prazo de cento e oitenta dias. Inconstitucionalidade formal.

O Supremo Tribunal Federal, no julgamento do Recurso Extraordinário n ${ }^{\circ}$ 229.450, Relator Ministro Maurício Corrêa, por maioria, declarou a inconstitucionalidade do artigo 77, inciso VII, da Constituição do Estado do Rio de Janeiro, que cria direito à nomeação dos candidatos aprovados em concurso público, dentro do número de vagas do edital do certame, e impõe a nomeação no prazo de cento e oitenta dias, por inobservância do princípio da reserva da iniciativa legislativa ao Chefe do Poder Executivo (Constituição Federal, artigo 61, parágrafo primeiro, inciso II, alínea "c").

Recursos conhecidos e providos. ${ }^{8}$

8 Recurso Extraordinário 191.089 - RJ, Relator Ministro Ilmar Galvão, 1a Turma, julgamento em 14 de março de 2000, votação unânime, publicação no Diário de Justiça em 28 de abril de 2000 , página 95, ementário volume 01986-05, página 846. 
No Recurso Extraordinário n 229.450 - RJ, Relator Ministro Maurício Corrêa, julgado em 10 de fevereiro de 2000, acórdão do Tribunal de Justiça do Estado do Rio de Janeiro assegurou a candidatos aprovados no concurso para provimento de cargos de fiscal do sistema viário o direito à nomeação, por força do disposto no supra mencionado artigo 77, inciso VII.

A questão versada lavrou dissensão: o Relator, acompanhado pelos eminentes Ministros Nelson Jobim, Ilmar Galvão, Sydney Sanches, Néri da Silveira e Moreira Alves, declarou a inconstitucionalidade da norma impugnada, uma vez que esta limitação temporal, ao restringir o poder discricionário do agente público, contraria o princípio da independência dos Poderes, conforme insculpido no artigo $2^{\circ}$ da Constituição da República.

Por outro lado, os Ministros Celso de Mello, Sepúlveda Pertence, Octávio Gallotti e Marco Aurélio entenderam que a Constituição Estadual pode limitar a discricionariedade dos Poderes, assegurando ao candidato aprovado em concurso público o direito subjetivo à nomeação.

Em outra oportunidade ${ }^{9}$, acrescentou a Suprema Corte, por maioria, que a obrigatoriedade da nomeação dos candidatos aprovados dentro do número de vagas previstas no edital ofende o artigo 61, parágrafo primeiro, inciso II, alínea "c", da Constituição da República, que confere ao Chefe do Poder Executivo a iniciativa privativa das leis que disponham sobre servidores e o provimento dos cargos públi$\cos$.

\section{$V I-$ Conclusão}

Em suma: onde não há dever jurídico, inexiste possibilidade de violação de direito subjetivo, eis que encontramo-nos no campo da mera expectativa de direito, que somente exsurgirá mediante inobservância à ordem classificatória ou deflagração de novo certame durante o prazo de eficácia do anterior.

\section{VII - Bibliografia}

MEIRELLES, Hely Lopes. Direito Administrativo Brasileiro. $19^{\mathrm{a}}$ ed. São Paulo, Malheiros Editores, 1994.

MOREIRA NETO, Diogo de Figueiredo. Curso de Direito Administrativo, $7^{\mathbf{a}}$ ed. Rio de Janeiro, Ed. Forense, 1989.

GASPARINI, Diogenes. Direito Administrativo. $4^{\mathrm{a}}$ ed. São Paulo, Ed. Saraiva, 1995. SUNDFELD, Carlos Ari, Fundamentos de Direito Público. São Paulo, Malheiros Editores, 1992.

9 Recurso Extraordinário n 190.264 - RJ, Relator Originário Ministro Marco Aurélio, Relator para acórdão Ministro Nelson Jobim. Julgamento em 10 de fevereiro de 2000. 